Utah State University

DigitalCommons@USU

The Bark Beetles, Fuels, and Fire Bibliography

Quinney Natural Resources Research Library,

S.J. and Jessie E.

1986

\title{
Mountain Pine Beetle Outbreaks in the Rocky Mountains: Regulators of Primary Productivity?
}

\author{
W. H. Romme \\ D. H. Knight \\ J. B. Yavitt
}

Follow this and additional works at: https://digitalcommons.usu.edu/barkbeetles

Part of the Entomology Commons, Forest Biology Commons, and the Forest Management Commons

\section{Recommended Citation}

Romme, W.H., D.H. Knight, and J.B. Yavitt. 1986. Mountain pine beetle outbreaks in the Rocky Mountains: Regulators of primary productivity? Am. Nat. 127(4):484-494

This Article is brought to you for free and open access by the Quinney Natural Resources Research Library, S.J. and Jessie E. at DigitalCommons@USU. It has been accepted for inclusion in The Bark Beetles, Fuels, and Fire Bibliography by an authorized administrator of DigitalCommons@USU. For more information, please contact digitalcommons@usu.edu.

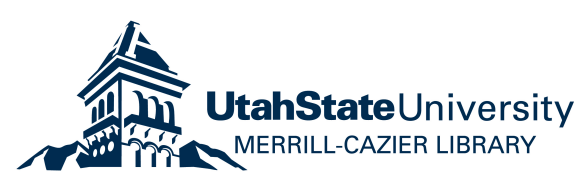




\title{
Utah State University
}

\section{DigitalCommons@USU}

The Bark Beetles, Fuels, and Fire Bibliography

Quinney Natural Resources Research Library, S.J.

and Jessie E.

1986

\section{Mountain pine beetle outbreaks in the Rocky Mountains: Regulators of primary productivity?}

\author{
W. H. Romme \\ D. H. Knight \\ J. B. Yavitt
}

Follow this and additional works at: https:// digitalcommons.usu.edu/barkbeetles

Part of the Entomology Commons, Forest Biology Commons, and the Forest Management Commons

\section{Recommended Citation}

Romme, W.H., D.H. Knight, and J.B. Yavitt. 1986. Mountain pine beetle outbreaks in the Rocky Mountains: Regulators of primary productivity? Am. Nat. 127(4):484-494

This Article is brought to you for free and open access by the Quinney Natural Resources Research Library, S.J. and Jessie E. at DigitalCommons@USU. It has been accepted for inclusion in The Bark Beetles, Fuels, and Fire Bibliography by an authorized administrator of DigitalCommons@USU. For more information, please contact dylan.burns@usu.edu.

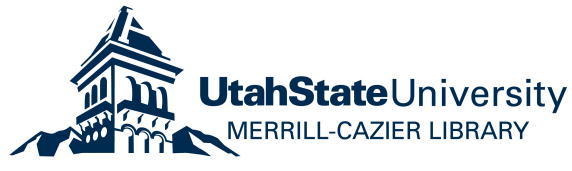




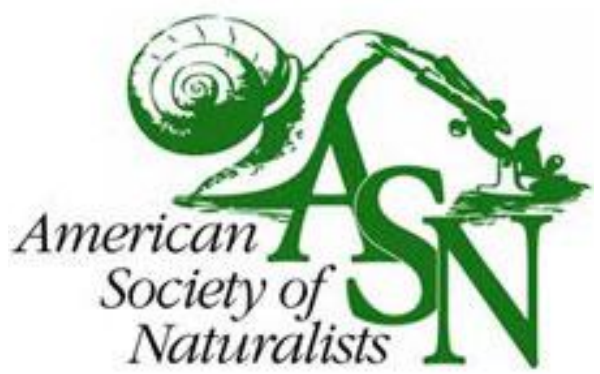

Mountain Pine Beetle Outbreaks in the Rocky Mountains: Regulators of Primary Productivity? Author(s): William H. Romme, Dennis H. Knight and Joseph B. Yavitt Source: The American Naturalist, Vol. 127, No. 4 (Apr., 1986), pp. 484-494

Published by: University of Chicago Press for American Society of Naturalists

Stable URL: http://www.jstor.org/stable/2461578

Accessed: 23-01-2016 21:16 UTC

Your use of the JSTOR archive indicates your acceptance of the Terms \& Conditions of Use, available at http://www.jstor.org/page/ info/about/policies/terms.jsp

JSTOR is a not-for-profit service that helps scholars, researchers, and students discover, use, and build upon a wide range of content in a trusted digital archive. We use information technology and tools to increase productivity and facilitate new forms of scholarship. For more information about JSTOR, please contact support@jstor.org. 


\title{
MOUNTAIN PINE BEETLE OUTBREAKS IN THE ROCKY MOUNTAINS: REGULATORS OF PRIMARY PRODUCTIVITY?
}

\author{
William H. Romme, Dennis H. Knight, ${ }^{*}$ and Joseph B. Yavitt*† \\ Department of Biology, Fort Lewis College, Durango, Colorado 81301; *Department of Botany, \\ University of Wyoming, Laramie, Wyoming 82071
}

Submitted November 7, 1983; Revised May 20, 1985; Accepted August 26, 1985

Major outbreaks of the mountain pine beetle (Dendroctonus ponderosae Hopk.) have killed millions of trees over thousands of square kilometers in the central and northern Rocky Mountains during recent years. This native bark beetle feeds on the phloem of various species of Pinus, introducing several species of sapwood fungi in the process (Amman 1978; Mitton and Sturgeon 1982). The beetles, which tend to selectively attack larger trees having thicker phloem, may kill $50 \%$ or more of the canopy density and basal area over a period of a few years. Understory and small canopy trees usually are not killed, apparently because they lack an adequate food supply for the beetles (Roe and Amman 1970; Amman and Baker 1972; Cole and Amman 1980). Although the population dynamics of the beetle and its effects on stand structure have been studied, little is known about the effects of a beetle outbreak on ecosystem processes such as productivity, cycling, and succession. Our study was designed to examine the effects of beetle outbreaks on primary productivity in forests dominated by lodgepole pine (Pinus contorta var. latifolia Engelm.) in northwestern Wyoming.

Although it is commonly assumed that phytophagous-insect outbreaks cause a reduction in primary productivity, such reductions may be of short duration. Mattson and Addy (1975) presented evidence suggesting that certain insects may stimulate primary productivity in forest ecosystems by selectively killing less productive plants or plant parts, thus enhancing light, water, and nutrient availability for survivors that had been suppressed by larger individuals. In this manner, the insects help to maintain a more even distribution of energy flow through the various ecosystem components, plant or animal, and probably contribute to maintaining a near-maximum level of primary productivity in the system (Berryman 1981). Similarly, McNaughton and Coughenour (1981) used the interaction between Dendroctonus brevicomis LeConte and Pinus ponderosa Laws. as an example illustrating the cybernetic nature of ecosystems. In one aspect of our investigation, we consider the hypothesis that the mountain pine beetle

\footnotetext{
$\dagger$ Present address: Department of Biology, West Virginia University, Morgantown, West Virginia 26506.
} 
functions as a cybernetic regulator of primary productivity in lodgepole pine forests.

Ecologists sometimes use the term "regulation"' loosely, referring to any mechanism that changes or influences an organism or process in any way. In the precise definition of cybernetic theory, a regulator responds to the state of a process or its output and, through some feedback mechanism, reduces the variation in the state or output of that process (Ashby 1963; Mattson and Addy 1975). Thus, to conclude that bark beetles function as cybernetic regulators (in the strict sense) of primary productivity we must demonstrate (1) that the insects can detect, and their behavior is modified by, the current level of primary productivity; and (2) that productivity is more constant or stable in the presence of the beetles than it is or would be in their absence. The first requirement appears to have been met at least partially by recent work showing that mountain pine beetles selectively attack trees of lower physiological vigor when the insects are at endemic population levels and in the early stages of outbreaks (Sartwell 1971; Berryman 1976, 1982; Larsson et al. 1983; Waring and Pitman 1983, 1985; Stuart 1984) and that outbreaks usually occur in mature or overmature stands that presumably have passed their period of peak productivity (Mitchell et al. 1983; Shrimpton and Thomson 1983; Waring and Pitman 1983). The observation that beetles may kill even vigorous, fast-growing trees at the height of an outbreak (Berryman 1976, 1982; Amman 1978) does not detract, in our opinion, from the feedback or detection-response requirement. (But see Cole et al. 1985 for the argument that tree diameter, not vigor, is the major variable controlling mountain pine beetle dynamics.) The second requirement, that of less-variable productivity, is more troublesome, however, and it is the focus of our paper. We ask whether forest productivity is more stable in the presence of periodic outbreaks than it would be without them.

The situation that we studied differs in two important respects from most of the examples of insect regulation proposed by Mattson and Addy (1975). First, they primarily examined light grazing by insects, rather than the substantial mortality associated with a beetle outbreak. They did suggest, however, that regulation may occur even in the more severe outbreak conditions. Second, unlike the defoliating insects emphasized by Mattson and Addy, the mountain pine beetle does not feed directly on the leaves, and because the beetles exist inside the bark, they do not immediately accelerate nutrient cycling by creating nutrient-rich litter fall (insect bodies, excrement, etc.). Nevertheless, successfully infested trees are usually dead within a year. Resource distribution occurs as a result of a leaf-fall episode lasting a few months and the toppling of dead trees over a period of more than $20 \mathrm{yr}$.

METHODS

Our study focused on a series of 10 stands affected by a major beetle outbreak from 1-20 yr ago. Each stand originated in a destructive fire 80-125 yr earlier and was dominated by an even-aged lodgepole pine canopy. All stands were located within $80 \mathrm{~km}$ of each other in southwestern Yellowstone National Park, northern 
Grand Teton National Park, or the adjacent Gallatin National Forest, at elevations of $1950-2440 \mathrm{~m}$.

In each stand we collected increment cores from surviving canopy, subcanopy, and understory trees in the summer of 1981. Some stands lacked subcanopy and/ or understory layers, apparently because of subtle differences in site factors or stand history unrelated to beetle activity. Where present, subcanopy and understory were composed of lodgepole pine and/or subalpine fir (Abies lasiocarpa (Hook.) Nutt.). In stands with high canopy mortality $(>40 \%)$, cores were taken randomly from survivors in each stratum. Where mortality was less severe, cores were taken mainly from survivors in the vicinity of trees killed by beetles.

In the lab we measured the mean annual ring width during the $5 \mathrm{yr}$ immediately preceding the beetle outbreak and during various 5-yr periods after the outbreak. We did not cross-date the rings, but our previous experience in this area indicated that false and missing rings are uncommon in lodgepole pine of this age. The approximate date of the peak outbreak ( $\pm 1-2 \mathrm{yr}$ ) was known for each stand from National Park Service and Forest Service records. Within this 2-4-yr period we generally found some year in which annual ring width increased dramatically; we assumed this to be the peak year. (This peak year is the summer after maximum tree mortality, not necessarily the time of highest beetle density.) We computed the ratio of mean annual ring width after the outbreak to mean width before to describe the change in tree growth following the outbreak. To account for the effects of climatic fluctuation on tree growth rates, we also collected cores from two control stands, which had a composition and structure similar to the other stands except that they had not yet been attacked by the beetles. For these control stands we computed similar ratios of mean annual ring width during the same years as for the beetle-affected stands.

In addition to measuring the response of individual surviving trees, it was also necessary to examine changes in total stand productivity following the beetle outbreak. To do this we sampled understory and canopy tree density before and after the beetle outbreak in four stands, using belt transects that covered about $30 \%$ of the stand area. Two of the stands had a well-developed understory of subalpine fir, and two had little or no understory. Trees killed by the beetles were identified by gallery etchings in the wood and/or by pitch tubes on the bark (Furniss and Carolin 1977). Because of slow decomposition in this area, trees killed by beetles as long as $20 \mathrm{yr}$ ago were still readily identifiable. Fallen trees were counted if they had been formerly rooted within the transect area.

Using radius measurements from our increment cores and field measurements of tree height, we estimated the bole volume of each sampled tree $5 \mathrm{yr}$ before the beetle outbreak and at 5-yr intervals after the outbreak. Bole volume was approximated using the formula for a cone $\left(V=1 / 3 \pi r^{2} H\right)$. Annual height increments in canopy and subcanopy trees were estimated using site index tables for lodgepole pine (Alexander 1966) and measurements of tree height in 1981. The mean annual height increment in understory subalpine fir was calculated from measurements of the increased height of the preceding $5 \mathrm{yr}$ in 25 randomly selected saplings. By subtracting and dividing by 5 , we estimated mean annual bole volume increment for each tree during every 5-yr period. Using the averages of the mean volume 
TABLE 1

Growth Response in Surviving Trees after a Major Beetle Outbreak

\begin{tabular}{|c|c|c|c|c|c|c|c|c|}
\hline \multirow{2}{*}{$\begin{array}{c}\text { Years } \\
\text { After } \\
\text { OUtBREAK }\end{array}$} & \multirow[b]{2}{*}{ StRatum } & \multicolumn{3}{|c|}{$\begin{array}{c}\text { BeETLE-AFFECTED } \\
\text { StANDS }\end{array}$} & \multicolumn{3}{|c|}{$\begin{array}{c}\text { Control } \\
\text { Stands }\end{array}$} & \multirow[b]{2}{*}{$P^{*}$} \\
\hline & & $\begin{array}{l}\text { Mean } \\
\text { Ratio }\end{array}$ & $n$ & $\mathrm{SE}$ & $\begin{array}{l}\text { Mean } \\
\text { Ratio }\end{array}$ & $n$ & $\mathrm{SE}$ & \\
\hline $1-5$ & Canopy & 1.21 & 59 & .07 & 0.94 & 162 & .02 & .001 \\
\hline $1-5$ & Subcanopy & 1.30 & 28 & .16 & 0.95 & 108 & .03 & $>.10 \mathrm{NS}$ \\
\hline $1-5$ & Understory & 1.68 & 23 & .14 & 0.99 & 72 & .04 & .001 \\
\hline $6-10$ & Canopy & 1.45 & 34 & .09 & 0.92 & 108 & .04 & .001 \\
\hline $6-10$ & Subcanopy & 2.16 & 15 & .31 & 0.95 & 54 & .05 & .001 \\
\hline $6-10$ & Understory & 3.45 & 21 & .37 & 0.84 & 54 & .04 & .001 \\
\hline $11-15$ & Canopy & 1.45 & 13 & .16 & 0.86 & 54 & .05 & .001 \\
\hline $11-15$ & Subcanopy & 3.06 & 10 & .90 & 0.92 & 36 & .05 & .001 \\
\hline $11-15$ & Understory & 2.81 & 16 & .29 & 0.82 & 36 & .06 & .001 \\
\hline $16-20$ & Canopy & 1.73 & 5 & .29 & 0.98 & 18 & .10 & .050 \\
\hline $16-20$ & Subcanopy & 3.66 & 5 & 1.92 & 0.98 & 18 & .10 & .010 \\
\hline
\end{tabular}

NOTE.-Growth response is expressed by the ratio of the mean annual ring width after the outbreak to the mean annual ring width during the $5 \mathrm{yr}$ just before the outbreak. This ratio was computed for each sampled tree; then the ratios for all trees in a given stratum were averaged to obtain a mean ratio and standard error of the mean (SE).

* Significance of the difference between the mean ratios in the beetle-affected stands and in the control stands, calculated using the Mann-Whitney $U$-test (two-tailed test) (Sokal and Rohlf 1981). NS, not significant.

increments from all of the trees for which we had estimates (treating canopy and understory trees separately), we then multiplied by the number of trees per hectare to arrive at mean annual bole volume increment per hectare before and after the beetle outbreak in the canopy and understory strata. We were unable to reconstruct patterns in leaf, branch, and root productivity, but changes in these other components of net primary productivity probably were similar to the changes that we reconstructed for wood production.

Finally, to examine patterns in wood production over a longer time, we reconstructed bole volume and stand density for the last $70-80 \mathrm{yr}$ in 2 of the 10 stands, using the methods described above. The reconstruction of stand 3, which had a sapling understory, was based on increment cores from all living and dead canopy trees (plus a subsample of 15 understory trees). The other stand had no understory, and the reconstruction was based on 10 cores from the even-aged canopy trees. Both stands contained some small trees that had died from causes other than the beetles (probably suppression mortality). We sampled these, estimated their year of death from their size and state of decomposition, and included them in our estimates of stand density for the last 70-80 yr.

\section{RESULTS}

Table 1 shows that surviving trees in all three strata grew more rapidly after the beetle outbreaks (i.e., ratio $>1.0$ ) during the entire 20 -yr period encompassed by our measurements. Furthermore, the ratios in the beetle-affected stands are 


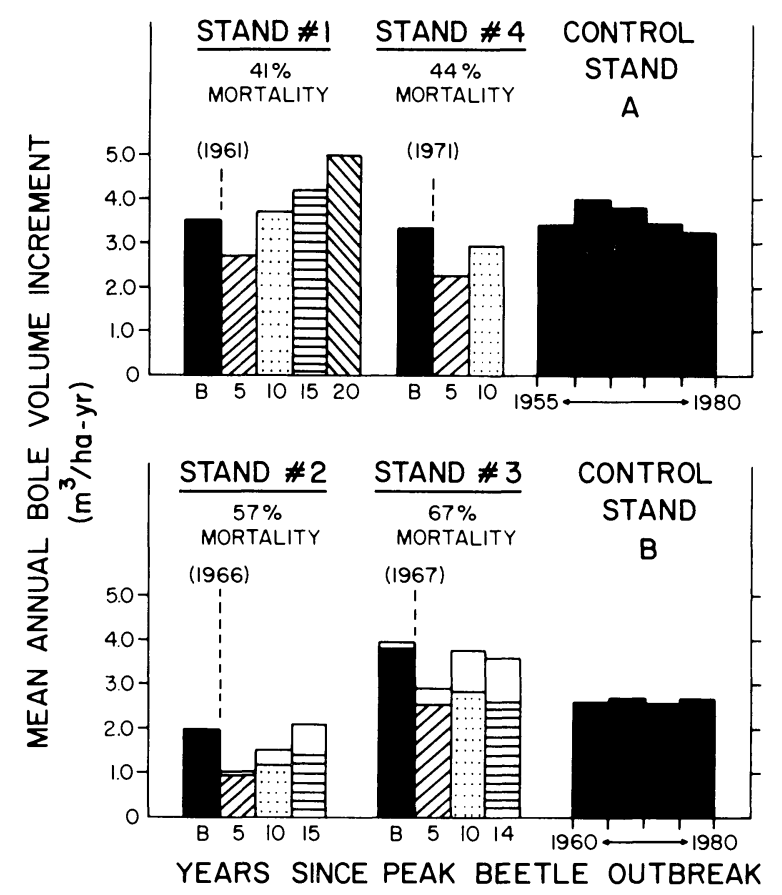

FIG. 1.-Mean annual bole volume increment in four stands during the $5 \mathrm{yr}$ before a beetle outbreak (B), 1-5 yr after the outbreak (5), 6-10 yr after (10), 11-14 yr after (14; stand 3 only), 11-15 yr after (15; stands 1, 2, 4), and 15-20 yr after (20; stand 1 only). Mean annual increments during comparable 5-yr periods are also shown for the two control stands. The open portions of the columns represent understory production; the patterned portions represent canopy and subcanopy production.

consistently greater than the ratios for the same years in the control stands. Since all but one of these differences are significant $(P<.10)$, we concluded that the more rapid growth was due to the effects of the beetles rather than to changes in precipitation or other external factors. Generally, the greatest increases in ring width were seen in the understory trees, followed by the subcanopy and then the canopy trees.

Short-term changes in total annual wood production are illustrated in figure 1. In stand 1 , the beetles reduced canopy density by $41 \%$. Annual wood production per hectare decreased during the first $5 \mathrm{yr}$ after the outbreak, returning to its former level after only 6-10 yr. Subsequent annual production was even higher than before the outbreak. Similarly, stand 4 (with $44 \%$ mortality) declined in productivity during the first $5 \mathrm{yr}$, but had nearly recovered after $10 \mathrm{yr}$. The two stands depicted at the bottom of figure 1 had greater canopy mortality, but also relatively dense understories. Again, wood production was reduced initially but approximated its former level within 11-15 yr, largely because of greatly increased understory production. Similar calculations made for the same time periods in the two control stands (fig. 1) show that the changes in productivity in 


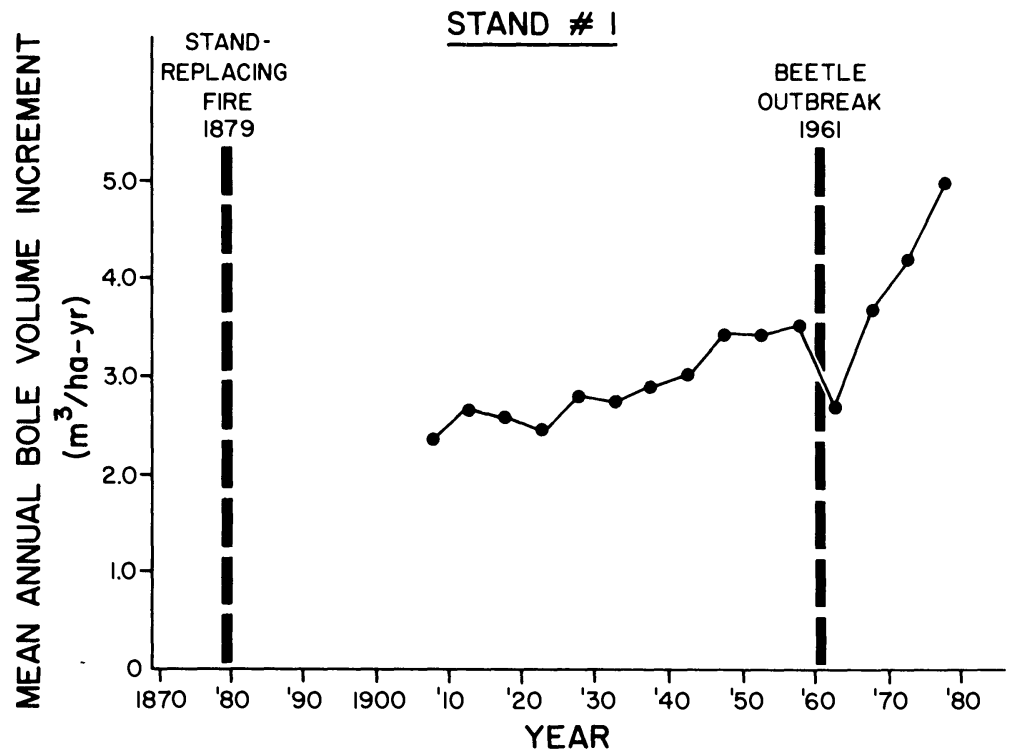

FIG. 2.-Reconstructed history of mean annual bole volume increment in a beetle-affected stand with little understory.

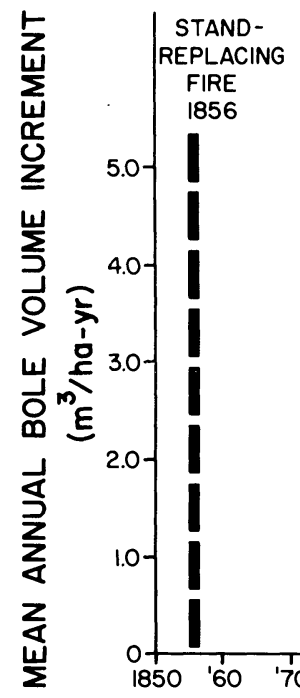

\section{STAND \# 3}

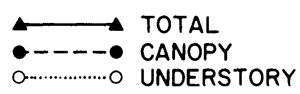

BEETLE

REPLACING

FIRE

1856

OUTBREAK

1967 
stands 1-4 probably result from beetle activity rather than changes in climate or other factors.

Longer-term reconstructions of annual wood production are shown for two stands in figures 2 and 3. Stand 1 (fig. 2) originated after a destructive fire in 1879 and was about $80 \mathrm{yr}$ old when the outbreak occurred in 1961; annual wood production had been increasing slowly since 1910. The apparent effect of the beetles was to accelerate wood production over what it had been before the outbreak. Stand 3 (fig. 3), about 125 yr old when the outbreak occurred in 1967, had a well-developed understory of subalpine fir; annual wood production apparently had peaked and leveled off in this stand before the outbreak. Total production was reduced by about $25 \%$ by the beetle outbreak, but it soon returned to near its former level as understory productivity rose sharply. It can be seen, however, that the relative contribution of the understory to total stand productivity had begun to increase even before the outbreak, through ordinary successional changes in stand structure.

\section{DISCUSSION}

It is clear from table 1 that individual surviving trees respond dramatically to the changes produced by a beetle outbreak. The mechanism apparently entails increased availability of light, water, and nutrients, one or more of which previously limited productivity in the smaller trees. Waring and Pitman (1985) concluded from a thinning and fertilization experiment in Oregon that tree growth improved after a beetle outbreak mainly because of increased light availability. Similar releases of surviving trees following the death, defoliation, or removal of a portion of the canopy have been described in both coniferous and deciduous forests from many parts of the world (Duncan and Hodson 1958; Collins 1961; Gordon 1973; Ferguson and Adams 1980; Ferrell 1980; Seidel 1980, 1983; Moore and Hatch 1981; Campbell and Garlo 1982; McCaughey and Schmidt 1982; Prudhomme 1982; MacLean 1984).

The question remains whether the accelerated growth of the survivors compensates for the lost productivity of the trees that have been killed. It appears from figure 1 that productivity does indeed recover rapidly. Despite the sudden and intensive alteration of stand structure brought on by a beetle outbreak, the resulting depression of stand productivity is remarkably small in magnitude (about $25 \%$, fig. 1) and brief in duration (5-15 yr, figs. 1-3). This resilience of the lodgepole pine forest might have been expected considering that the pine and beetle have a long history of coevolution (Mitton and Sturgeon 1982) and that various resources are limiting to tree growth, especially in mature stands (Waring and Pitman 1985; T. J. Fahey and Knight, in prep.). Along with the measured increases in wood production of formerly suppressed trees, there are probably also increases in tree foliage and root production, as well as in ground-layer shrubs and herbs (McCambridge et al. 1982; Waring and Pitman 1985).

One overall effect of a beetle outbreak thus appears to be greater equitability of biomass and energy flow among the various components of the ecosystem. Lodgepole pine forests around a hundred years old in the Yellowstone area 
usually have a simple structure, consisting of an even-aged canopy, a sparse sapling understory, and a low ground layer of shrubs and herbs. It appears that before an outbreak, biomass and productivity are overwhelmingly concentrated in the dominant canopy stratum, but afterward they are distributed somewhat more evenly among the three strata. In turn, the biomass and productivity of herbivores, decomposers, and other organisms associated with each of the subdominant strata may be increased by the beetle-induced changes. Thus, the beetles appear to enhance the complexity and diversity of the community, not so much with respect to species diversity, which is characteristically low in these forests and probably does not change substantially after a beetle outbreak, but with respect to the allocation of resources among the structural components of the system. From this perspective, the effects of the beetle outbreaks are similar to the effects of other natural disturbances and predators, which tend to reduce the abundance of the more competitive species in a community (Paine 1974; Connell 1978; Huston 1979).

Our results resemble those of Mattson and Addy (1975) and Moore and Hatch (1981), who showed through simulation studies that outbreaks of spruce budworm and Douglas fir tussock moth, respectively, led to a redistribution of wood production from canopy to understory or from host to nonhost species. Moreover, in Mattson and Addy's simulation, total stand productivity was greater in the infested stand than in the control, indicating that the insects actually increased the total energy flow as well as redistributing it. Our own results suggest considerable variability in subsequent productivity. In stand 1 (fig. 1) the beetles apparently increased productivity over pre-outbreak levels (following a short lag period), whereas productivity simply returned to previous levels in the other three stands.

But our primary concern is not whether an insect outbreak redistributes energy flow or increases or decreases total primary productivity, for the essential quality of a cybernetic regulator is its ability to reduce variation in the output of a process and to hold that output within some acceptable range (Ashby 1963; Mattson and Addy 1975). This leads immediately to a difficult conceptual problem. What is the acceptable range, or target, for primary productivity in this or any ecosystem?

One possible solution is to assert that the target is the maximum sustainable primary productivity that can be achieved between perturbations such as fire given the resources available to the system. This is the target that Mattson and Addy seemed to assume in their discussion, and it is possible that selection might tend to maximize productivity, but not standing crop, at all trophic levels (Berryman 1981). Do mountain pine beetles tend to hold the primary productivity of lodgepole pine forests near the maximum possible level? Figure 1 suggests that, over the short term (5-20 yr), the beetles actually introduced more variation into the output than would have existed in their absence; wood production was much more constant in the two control stands than in the beetle-affected stands.

Could the role of beetles as regulators be more apparent over the long term? Mattson and Addy (1975) emphasized that insect outbreaks often occur in forests that are mature or overmature, that is, in those that have already passed their peak in biomass production. Figures 2 and 3 suggest that beetle outbreaks can occur before any decline in wood production is obvious, though both stands had experi- 
enced more-rapid growth rates earlier in their history. Primary productivity probably does decline in lodgepole pine forests older than those we studied, although we have no empirical data to support this assertion.

Let us for the moment assume that productivity in these very old stands is stimulated by the beetles' thinning. Even if true, the increases in productivity induced by a beetle outbreak are surely small compared with the enormous alterations introduced by stand-replacing fires, which occur at intervals of 200$400 \mathrm{yr}$ (the prehistoric fire regime for this area; Romme 1982) and which produce not constant rates of production but cyclic oscillations of great magnitude in any individual stand. If we consider the entire forest landscape, comprising a mosaic of stands in various stages of succession, then annual productivity for the landscape as a whole could be relatively constant despite the continual fluctuations of individual stands (Loucks 1970; Schowalter et al. 1981; Shugart and West 1981; Romme and Knight 1982; Sprugel 1984). From this perspective, fire may indeed exert a stabilizing control over productivity, but at a level below the maximum because the landscape always contains nonproductive as well as productive stands. Beetle outbreaks may increase the risk of fire in a stand (Geiszler et al. 1980), but fire is clearly the dominant factor.

In conclusion, our approach has not demonstrated that mountain pine beetles function as cybernetic regulators (in the strict sense) of primary productivity. The trees affect the beetles as well as the reverse; and other factors, such as periodic fire and the physical environment, tend to dominate ecosystem processes. What impresses us more than the regulatory role of one component is the resilience of the system as a whole, which can be attributed to the responses of individual organisms to resource availability. A massive and sudden disturbance (the death of a large fraction of the autotrophic biomass within a few years) leads to only a brief drop in primary productivity and to a more equitable distribution of biomass and resources.

\section{SUMMARY}

We consider the hypothesis that mountain pine beetles function as cybernetic regulators of primary productivity in ecosystems of lodgepole pine forest through their selective killing of dominant trees and the subsequent redistribution of resources. Following a recent major beetle outbreak in Yellowstone and Grand Teton national parks, surviving trees did grow significantly faster $(P<.1)$; wood production was redistributed among canopy, subcanopy, and understory trees; and annual wood production per hectare usually returned to pre-attack levels or exceeded them within 10-15 yr. However, reconstructions of annual wood production over the last 70-80 yr indicate that the beetle outbreak did not reduce the variation in productivity; rather, the beetles introduced more variation than would have existed in their absence. Hence, our results do not support the hypothesis that the beetles function as cybernetic regulators (in the strict sense).

Nevertheless, the beetle-pine system that we studied shows great resilience, and the effects of beetles on primary productivity do not appear to be as severe as conventional wisdom maintains. Annual wood production per hectare returned 
quickly to previous levels in the stands we studied, and associated ecological changes can be considered generally benign or even beneficial.

\section{ACKNOWLEDGMENTS}

We thank H. Romme and G. Watson for field assistance; W. Lynch and N. Sferra for laboratory help; J. Fedders for assistance with the stand-volume reconstructions; and S. McNaughton, R. Peet, A. Berryman, and two anonymous reviewers for helpful comments on the manuscript. This research was supported by grants from the University of Wyoming-National Park Service Research Center, the Eastern Kentucky University Institutional Research Fund, and National Science Foundation grant DEB 80-11024.

\section{LITERATURE CITED}

Alexander, R. R. 1966. Site indexes for lodgepole pine, with corrections for stand density: instructions for field use. U.S. For. Serv. Res. Pap. RM-24.

Amman, G. D. 1978. Biology, ecology, and causes of outbreaks of the mountain pine beetle in lodgepole pine forests. Pages 39-53 in D. L. Kibbee, A. A. Berryman, G. D. Amman, and R. W. Stark, eds. Theory and practice of mountain pine beetle management in lodgepole pine forests. Forest, Wildlife, and Range Experiment Station, University of Idaho, Moscow.

Amman, G. D., and B. H. Baker. 1972. Mountain pine beetle influence on lodgepole pine stand structure. J. For. 70:204-209.

Ashby, W. R. 1963. An introduction to cybernetics. Wiley, New York.

Berryman, A. A. 1976. Theoretical explanation of mountain pine beetle dynamics in lodgepole pine forests. Environ. Entomol. 5:1225-1233.

1981. Population systems: a general introduction. Plenum, New York.

1982. Mountain pine beetle outbreaks in Rocky Mountain lodgepole pine forests. J. For. $80: 410-413,419$.

Campbell, R. W., and A. S. Garlo. 1982. Gypsy moth in New Jersey pine-oak. J. For. 80:89-90.

Cole, W. E., and G. D. Amman. 1980. Mountain pine beetle dynamics in lodgepole pine forests. 1. Course of an infestation. U.S. For. Serv. Gen. Tech. Rep. INT-89.

Cole, W. E., G. D. Amman, and C. E. Jensen. 1985. Mountain pine beetle dynamics in lodgepole pine forests. III. Sampling and modeling of mountain pine beetle populations. U.S. For. Serv. Gen. Tech. Rep. INT-188.

Collins, S. 1961. Benefits to understory from canopy defoliation by gypsy moth larvae. Ecology 42:836-838.

Connell, J. H. 1978. Diversity in tropical rain forests and coral reefs. Science (Wash., D.C.) 199: 1302-1310.

Duncan, D. P., and A. C. Hodson. 1958. Influence of the forest tent caterpillar upon the aspen forests of $N$ " iesota. For. Sci. 4:71-93.

Ferguson, D. E., and D. L. Adams. 1980. Response of advance grand fir regeneration to overstory removal in northern Idaho. For. Sci. 26:537-545.

Ferrell, G. T. 1980. Growth of white firs defoliated by Modoc budworm in northeastern California. U.S. For. Serv. Res. Pap. PSW-153.

Furniss, R. L., and V. M. Carolin. 1977. Western forest insects. U.S. For. Serv. Misc. Publ. 1339.

Geiszler, D. R., R. I. Gara, C. H. Driver, V. F. Gallucci, and R. E. Martin. 1980. Fire, fungi, and beetle influences on a lodgepole pine ecosystem of south-central Oregon. Oecologia (Berl.) 46:239-243.

Gordon, D. T. 1973. Released advance reproduction of white and red fir . . growth, damage, and mortality. U.S. For. Serv. Res. Pap. PSW-95.

Huston, M. 1979. A general hypothesis of species diversity. Am. Nat. 113:81-101. 
Larsson, S., R. Oren, R. H. Waring, and J. W. Barrett. 1983. Attacks of mountain pine beetle as related to tree vigor of ponderosa pine. For. Sci. 29:395-402.

Loucks, O. L. 1970. Evolution of diversity, efficiency, and community stability. Am. Zool. 10:17-25.

MacLean, D. A. 1984. Effects of spruce budworm outbreaks on the productivity and stability of balsam fir forests. For. Chron. 60:273-279.

Mattson, W. J., and N. D. Addy. 1975. Phytophagous insects as regulators of forest primary production. Science (Wash., D.C.) 190:515-522.

McCambridge, W. F., M. J. Morris, and C. B. Edminster. 1982. Herbage production under ponderosa pine killed by the mountain pine beetle in Colorado. U.S. For. Serv. Res. Note RM-416.

McCaughey, W. W., and W. C. Schmidt. 1982. Understory tree release following harvest cutting in spruce-fir forests of the intermountain west. U.S. For. Serv. Res. Pap. INT-285.

McNaughton, S. J., and M. B. Coughenour. 1981. The cybernetic nature of ecosystems. Am. Nat. 117:985-990.

Mitchell, R. G., R. H. Waring, and G. B. Pitman. 1983. Thinning lodgepole pine increases tree vigor and resistance to mountain pine beetle. For. Sci. 29:204-211.

Mitton, J. B., and K. B. Sturgeon, eds. 1982. Bark beetles in North American conifers: a system for the study of evolutionary biology. University of Texas Press, Austin.

Moore, J. A., and C. R. Hatch. 1981. A simulation approach for predicting the effect of Douglas-fir tussock moth defoliation on juvenile tree growth and stand dynamics. For. Sci. 27:685-700.

Paine, R. T. 1974. Intertidal community structure: experimental studies on the relationship between a dominant competitor and its principal predator. Oecologia (Berl.) 15:93-120.

Prudhomme, T. I. 1982. The effect of defoliation history on photosynthetic rates in mountain birch. Rep. Kevo Subarct. Res. Stn. 18:5-9.

Roe, A. L., and G. D. Amman. 1970. The mountain pine beetle in lodgepole pine forests. U.S. For. Serv. Res. Pap. INT-71.

Romme, W. H. 1982. Fire and landscape diversity in subalpine forests of Yellowstone National Park. Ecol. Monogr. 52:199-221.

Romme, W. H., and D. H. Knight. 1982. Landscape diversity: the concept applied to Yellowstone Park. BioScience 32:664-670.

Sartwell, C. 1971. Thinning ponderosa pine to prevent outbreaks of mountain pine beetle. Pages 41-52 in D. M. Baumgartner, ed. Precommercial thinning of coastal and intermountain forests in the Pacific Northwest. Washington State University Cooperative Extension Service, Pullman.

Schowalter, T. D., R. N. Coulson, and D. A. Crossley, Jr. 1981. Role of southern pine beetle and fire in maintenance of structure and function of the southeastern coniferous forest. Environ. Entomol. 10:821-825.

Seidel, K. W. 1980. Diameter and height growth of suppressed grand fir saplings after overstory removal. U.S. For. Serv. Res. Pap. PNW-275.

1983. Growth of suppressed grand fir and Shasta red fir in central Oregon after release and thinning-10-year results. U.S. For. Serv. Res. Note PNW-404.

Shrimpton, D. M., and A. J. Thomson. 1983. Growth characteristics of lodgepole pine associated with the start of mountain pine beetle outbreaks. Can. J. For. Res. 13:137-144.

Shugart, H. H., Jr., and D. C. West. 1981. Long-term dynamics of forest ecosystems. Am. Sci. 69:647-652.

Sokal, R. R., and F. J. Rohlf. 1981. Biometry. 2d ed. Freeman, San Francisco.

Sprugel, D. G. 1984. Density, biomass, productivity, and nutrient-cycling changes during stand development in wave-regenerated balsam fir forests. Ecol. Monogr. 54:165-186.

Stuart, J. D. 1984. Hazard rating of lodgepole pine stands to mountain pine beetle outbreaks in southcentral Oregon. Can. J. For. Res. 14:666-671.

Waring, R. H., and G. B. Pitman. 1983. Physiological stress in lodgepole pine as a precursor for mountain pine beetle attack. Z. Angew. Entomol. 96:265-270.

1985. Modifying lodgepole pine stands to change susceptibility to mountain pine beetle attack. Ecology 66:889-897. 